\title{
Chemical substitution mechanisms of muscovite from rare-metal pegmatites of Renli deposit, SE China
}

\author{
PENG LI, JIANKANG LI AND ZHENYU CHEN
}

Institute of Mineral Resources, Chinese Academy of Geological Sciences

Presenting Author: lipeng031111@163.com

The giant Renli rare-metal deposit in northern Hunan province of China is located at the south margin of the Mufushan batholith. From NE to SW, outcropping pegmatite dykes in the deposit can be approximately divided into four zones from near to far from the Mufushan batholith: microcline pegmatite zone (P1); microcline-albite pegmatite zone (P2); albite pegmatite zone (P3); and albite-spodumene pegmatite zone (P4). Correspondingly, with the distance from the batholith, the dominant alikaline elements change from $\mathrm{K}$ to $(\mathrm{K}+\mathrm{Na})$ to $\mathrm{Na}$ and then to $(\mathrm{Na}+\mathrm{Li})$, the scales of the dykes decrease, and the raremetal mineralization type changes from single to complex $(\mathrm{Be} \rightarrow \mathrm{Be}+\mathrm{Nb}+\mathrm{Ta} \rightarrow \mathrm{Be}+\mathrm{Nb}+\mathrm{Ta}+\mathrm{Li})^{[1,2]}$.

Chemical analyses of 40 primary muscovite samples from the four types of pegematites show that the substitution exchange vectors of $4 \mathrm{Al}^{\mathrm{Tot}} \leftrightarrow 3 \mathrm{Si}^{\mathrm{IV}}+\square^{\mathrm{VI}}$ and $3 \mathrm{Li}^{\mathrm{VI}} \leftrightarrow \mathrm{Al}^{\mathrm{VI}}+2 \square^{\mathrm{VI}}$ ( $\square$ represents a vacancy) are the dominant mechanisms of the muscovite-lepidolite series in the Renli deposit, indicating that the deposit experienced two magmatic evolution stages. The $\mathrm{Al}_{4} \mathrm{Si}_{-3} \square_{-1}$ exchange vector was critical in the first magmatic stage of the Renli deposit, and compositional changes in Li-poor muscovite formed in the magmatic stage involved this substitution. However, during the late fluid-rich stage at the end of the deposit's magmatic evolution, this mechanism had lesser influence. Instead, the $\mathrm{Li}_{3} \mathrm{Al}_{-1} \square_{-2}$ vector principally controlled the composition of later micas, causing $\mathrm{Li}$ to be incorporated into the micas by $\mathrm{Li}_{3} \mathrm{Al}_{-1} \square_{-2}$ during the fluid-rich stage.

[1] Li et al. (2019), Ore Geol Rev 115, 103187. [2] Li et al. (2020), Ore Geol Rev 116, 103237. 